\title{
Mercury Phytoremediation with Lolium perenne-Mycorrhizae in Contaminated Soils
}

\author{
Ana M. Leudo ${ }^{1,2}{ }^{\text {, Yuby Cruz }}{ }^{1}$, Carolina Montoya-Ruiz ${ }^{2}$, María del Pilar Delgado ${ }^{2}$ (I) and \\ Juan F. Saldarriaga $1, * \mathbb{D}$ \\ 1 Department of Civil and Environmental Engineering, Universidad de los Andes, Carrera 1Este \#19A-40, \\ Bogotá 111711, Colombia; am.leudo10@uniandes.edu.co (A.M.L.); yd.cruz10@uniandes.edu.co (Y.C.) \\ 2 Department of Biological Sciences, Universidad de los Andes, Carrera 1 \#18A-10, Bogotá 111711, Colombia; \\ c.montoyar1@uniandes.edu.co (C.M.-R.); mdelgado@uniandes.edu.co (M.d.P.D.) \\ * Correspondence: jf.saldarriaga@uniandes.edu.co or juanfelorza@gmail.com
}

Received: 26 March 2020; Accepted: 27 April 2020; Published: 7 May 2020

\begin{abstract}
The symbiotic association between the roots of a plant and the mycelium of some fungi is identified as mycorrhizae. Symbiosis helps the plant to obtain nutrients from the soil more efficiently, and may favor the phytoremediation capacity of plants such as Lolium perenne, in soils contaminated with mercury. In this study, the morphological and molecular response was evaluated, as well as the variation in mercury accumulation in the different structures of L. perenne when associated with arbuscular mycorrhizal fungi. Association tests were performed to determine the optimal concentration of the biological inoculant and it was found that the best results were given with the proportion of one part of inoculant in three parts of soil ( $w / w$ ratio). The differential expression of the glutathione-S-transferase GST gene was evaluated through real-time PCR and the concentration of heavy metals inside and outside the plant was evaluated with inductively coupled plasma atomic emission spectroscopy (ICP). It was found that the plants that were inoculated with mycorrhizae developed longer stems and shorter roots; in the same way, the GST gene had greater expression in the stem than in the root, largely because the roots help the filtration of nutrients to the stem, retaining metals and detoxifying by GST-catalyzed glutathione.
\end{abstract}

Keywords: phytoremediation; mycorrhiza; mercury; GST expression; Lolium perenne

\section{Introduction}

Elemental mercury gas comes from volcanic eruptions and anthropogenic processes such as the burning of products derived from oil, coal, and other fossil fuels. Mercury has a residence time of the order of one year in the air [1]. The accumulation and spread of this metal can be evidenced in peat soils [2,3]. When mercury is oxidized to inorganic $\mathrm{Hg}$ (II) it is deposited in soils and oceans, then it is transported over a long distance resulting in accumulation in soils and sediments that can exceed pre-industrial concentrations by 2-5 times [2]. The biogeochemistry of mercury is complicated and involves all chemical states, solid, liquid, gaseous, and aqueous. Under oxidation conditions, inorganic $\mathrm{Hg}$ with oxidation state $+\mathrm{II}$ is predominant. This oxidation state forms complexes dissolved with organic and inorganic ligands, surface complexes with particles, as well as solid phases with main sulfides ( $\alpha$ - and $\beta-\mathrm{HgS}$ ). Alkylated forms are of greatest concern today and monomethyl mercury $\left(\mathrm{CH}_{3} \mathrm{Hg}\right.$ or $\left.\mathrm{MeHg}\right)$ is the most abundant in the environment [4].

In Sweden, 40,000 lakes have MeHg concentrations in fish that exceed the levels established by the health authorities for human consumption [4-6]. Conventional treatments to mitigate mercury contamination in soils include solidification, soil washing, stabilization, vitrification, soil vapor 
extraction, and electrokinetic remediation. These methods are expensive and have great negative impacts on soil properties $[7,8]$.

On the other hand, biological treatments such as bioremediation and phytoremediation may be a potentially viable option in the treatment of contaminated soils $[9,10]$. Phytoremediation is broadly defined as the use of potential plants (hyperaccumulators) in the removal/extraction of metallic contaminants from contaminated soils [8]. This treatment is highly effective, and environmentally and economically sustainable compared to conventional treatment methods. However, the interaction between the environment and plants has had a constant evolution, determined by biological processes such as photosynthesis, germination, growth, and/or reproduction [11,12]. It is for this reason that these processes must be taken into account when evaluating a plant as a phytoremediator.

Among biotic factors, soil microorganisms are a crucial group that affects plant establishment and development [13]. Mycorrhizal fungi are one of the most outstanding organisms due to their interaction with plant roots [14,15]. These are strict biotrophic fungi, which obtain all their carbohydrates [16] and lipids [17] from their host plants, leading to the incorporation of nutrients from the soil being mainly phosphorus and other minerals [11,16]. Approximately $80 \%$ of plant species have this type of association throughout their growth $[18,19]$, and it has been described that $95 \%$ of these associations correspond to arbuscular endomycorrhizae, characterized by the absence of a fungal mantle $[15,20]$ and the presence of a branched hyphal shrub in the cells of the root cortex $[15,18,20]$. There are three families of fungi capable of forming arbuscular endomycorrhizae, which are divided into six genera $[18,19]$. The most common family is Glomaceae, which is made up of the Glomus and Sclerocystis genera, followed by the Acaulosporaceae family made up of the Acaulospora and Entrophospora genera, and finally, the Gigasporaceae family made up of the Gigaspora and Scutellospora genera [18].

In general, the associations between plants and fungi are beneficial for both; the fungus obtains photosynthetic products and carbonaceous compounds, while the plant receives mineral nutrients from the symbiote mycelium [16]. In addition to the ease of obtaining nutrients, this association can increase growth and improve the reproductive abilities of the plant since the mycorrhiza generates a direct bridge between the soil and the root, and increases the surface of absorption of water and mineral nutrients [21]. It can also help a plant develop tolerance to different environmental conditions such as soils contaminated by metals and organic compounds, among others. In some plant species it has been found that this association can contribute to the removal and degradation of different pollutants such as heavy metals and light hydrocarbons from the soil [8,21-24].

One of the main consequences of plant exposure to heavy metals is the generation of reactive oxygen species (ROS), which can cause lipid peroxidation, membrane damage, and enzyme inactivation [25]. To reduce the toxic effects of ROS, plants initiate the ROS elimination systems by increasing the gene expression of some detoxification enzymes such as glutathione-S-transferase [26]. GSTs are a family of enzymes that are notable for their role in phase II detoxification reactions, which are found in all organisms. The GSTs conjugate GSH to an array of electrophilic compounds of exogenous and endogenous origin. In plants, members of the GST family are herbicide tolerant, protecting cells against chemical-induced toxicity and providing tolerance by catalyzing S-conjugation between the thiol group of GSH and the electrophilic moiety in the hydrophobic and toxic substrate [27-29]. The identification of genes involved in the mechanisms involved in the growth of certain plants in contaminated soils has emerged as a promising approach both to assess the phytoremediation capacity of some species and their mechanisms of detoxification involved, as well as to establish principles for gene editing, to improve the tolerance of some plant species.

In plants, the phytoaccumulation capacity and the stress generated by the presence of heavy metals can be estimated in different ways. One of these is the quantification of metals absorbed by the different plant structures (stem, root, and leaves), by inductively coupled plasma atomic emission spectroscopy (ICP) [30]. Additionally, the identification of differential gene expression by real-time qPCR or RT-qPCR of genes involved in detoxification allows us to identify the response to stress generated by the presence of metals. 
Among the most important metabolites produced to counteract the stress caused by growth in media with past metals is glutathione ( $\alpha$-glutamyl-cysteinyl-glycine), which acts both as a reducing agent, protecting the cell against oxidative stress, and as a nucleophile, protecting against chemical toxicity through phase II detoxification reactions [31]. Coleman et al. [31] argue that homeostatic glutathione concentrations in plant cells are normally maintained through a series of interrelated processes, such as synthesis, degradation, and long-distance transport. Glutathione in its role as nucleophilic scavenger may undergo spontaneous or glutathione-S-transferase (GST) conjugation to a wide range of xenobiotic electrophiles [31].

Perennial ryegrass (Lolium perenne) is a diploid species of external breeding with a strong system of self-compatibility, and for this reason it is one of the most cultivated grasses in temperate regions $[25,32,33]$. The tolerance of $L$. perenne to saline conditions and different metals including mercury has been evaluated, but the changes in the gene expression of GST in L. perenne have not been evaluated [25,34-36]; similarly, compared to other perennial grass species, it is one of the most widely available sequences of both its genome and messenger RNA, facilitating its study and possible manipulation $[37,38]$. Therefore, ryegrass could serve as a mercury phytoremediator plant because previous studies have found that this plant is tolerant of growth in cadmium-contaminated media [39-41].

This work aimed to evaluate the phytoremediation potential of the symbiosis of $L$. perenne and mycorrhizal fungi as an alternative to the recovery of soils contaminated with mercury. Further, it aimed to determine the morphological changes and the expression of the GST gene of L. perenne involved in processes of phytotoxicity of metals in the presence of said symbiosis.

\section{Materials and Methods}

\subsection{Materials}

The experiment was divided into three stages: (i) association tests (root-fungus), (ii) seeding and sample collection, and (iii) morphological and molecular analysis, involving evaluation of gene expression and determination of the accumulation of heavy metal metals. Certified L. perennial seeds referenced as Rye Grass Bestfort plus (CEBA, Bogotá, Colombia) were used. Before being used they were washed with deionized water and $10 \% \mathrm{KOH}$ solution.

The reference Tierra Bona (Fercon S.A., Cali, Colombia) was used for the soil and two commercial preparations were used to form the mycorrhizae. The first preparation was "MICORRIZAR Biological Soil Inoculant" (AGROTECNIA LTDA, Bogotá, Colombia), which is roots colonized with a mixture of spores of the genera Glomus sp., Acaulospora sp., Entrophospora sp., and Giaspora sp., (MICO1). The second brand is known as "MICORRIZAS M.A soil inoculant" (SAFER AGROBIOLÓGICOS S.A.S, Bogotá, Colombia), which like the first is colonial roots that contain spores of the genera Glomus sp., Acaulospora sp., Entrophospora sp., and Scutellospora sp. (MICO2).

\subsection{Methods}

\subsubsection{Association Test}

In the association test, two commercial brands of commercial mycorrhizal preparations with L. perenne were used, as described above, to verify which of the two developed associations when viewed under a microscope. The mycorrhizae were seeded in $10 \mathrm{~cm}$-diameter Petri dishes, along with the soil in different proportions: 1:1, 1:2, 1:3, 1:4, 1:5, and 1:6 (w/w ratio) for a total of $40 \mathrm{~g}$ of mycorrhizal-soil mixture (metals and biological pollutants-free). In each Petri dish, 45 L. perenne seeds were sown and allowed to grow for 15 days with a 12/12-h photoperiod and were irrigated with deionized water. After this time, five seedlings for each rhizobox were randomly collected and a $\mathrm{KOH}$ staining was carried out at their roots. Each treatment included a negative control without mycorrhiza. This test was performed in duplicate. 
At the end of the association tests, it was obtained that the lowest ratio with which the association between the fungi and the plant occurred was 1:3; therefore, this ratio was the one used for the final sowing.

\subsection{2. $\mathrm{KOH}$ Staining}

For the staining of the roots, the methodology used was proposed by Cepero de García et al. [42] with some modifications that included shorter times in the rinsing and staining phase, since the protocol is designed to stain much thicker roots. This procedure consisted of collecting all the roots and washing them with deionized water to remove all the adhered soil. Subsequently, they underwent a rinsing process for $2 \mathrm{~h}$ with $10 \% \mathrm{KOH}$. The roots were again washed with deionized water to continue the rinsing process by immersing them in $3 \% \mathrm{H}_{2} \mathrm{O}_{2}$ for $20 \mathrm{~min}$.

After the rinsing process, the roots were immersed in a $1 \% \mathrm{HCl}$ solution for $10 \mathrm{~min}$, after which the trypan blue solution staining was made up of 50 parts of glycerol, 50 parts of lactic acid, and 0.05 parts of trypan blue, for $5 \mathrm{~min}$. Stained roots were observed under a microscope at $10 \times, 40 \times$ and $100 \times$ magnification.

\subsubsection{Soil Contamination}

To evaluate the growth of L. perenne in contaminated soils, the soil was contaminated in such a way that it had a final concentration of $1.0 \pm 0.2 \mathrm{mg} / \mathrm{kg}$ mercury [43], in accordance with the methodology proposed by Pitombeira et al. [44]. In total, $4 \mathrm{~kg}$ of soil was contaminated with mercury.

To confirm the final concentration of the contaminated soil, $1.0 \mathrm{~g}$ of it was collected, and acid digestion was performed following the EPA-3051A standard [45]. The samples were stored for one week. After that the leachate was analyzed using an ICP-OES Thermo Scientific ${ }^{\mathrm{TM}}$ ICAP6500 DUO (Waltham, MA, USA), according to the EPA-6010D method, the recovery percentage of mercury being $98 \%$.

\subsubsection{Planting in Contaminated Soil}

Four treatments were evaluated in duplicate. Taking into account that the best ratio was one part of mycorrhiza to three parts of soil, the quantities of each are shown in Table 1.

Table 1. Treatments used for the mercury phytoremediation process.

\begin{tabular}{ccc}
\hline Treatment & Amount of Soil (g) & Amount of Mycorrhiza (g) \\
\hline B (control) & $1000^{*}$ & - \\
BM (control with mycorrhizae) & 667 & 333 \\
H (mercury) & 1000 & - \\
HM (mercury with mycorrhizae) & 667 & 333 \\
\hline
\end{tabular}

* Rhizobox capacity.

In each rhizobox (with dimensions of $20 \mathrm{~cm}$ long, $10 \mathrm{~cm}$ wide, and $13 \mathrm{~cm}$ high) 200 seeds of L. perenne were sown evenly to obtain enough material for all the analyses to be carried out at the time of harvest at 30 days. The treatments used in the rhizobox culture were control (B), control with mycorrhizae (BM), mercury (H), and mercury with mycorrhizae (HM). During the 30 days of growth the seedlings were irrigated with distilled water $(207.5 \mathrm{~mL})$ to maintain humidity at $70 \%$. The watering was done on Mondays and Fridays at 8 am; likewise, the laboratory conditions were a relative humidity of $52 \%$, with an average temperature of $20 / 16^{\circ} \mathrm{C}$ (light/day), and the plants were exposed to a $12 \mathrm{~h} / 12 \mathrm{~h}$ photoperiod. Soil properties are summarized in Table 2. After 30 days, when the seedlings were collected, $95 \%$ of the plants showed uniformity in growth, and there were two biological samples $(n=2)$ per modality to carry out the analyses: molecular and heavy metal. Stems, and roots were measured with a PCE-DCP $600 \mathrm{~N}$ vernier caliper (HOPEX ${ }^{\circledR}$, Bogotá, Colombia) with an accuracy of $0.01 \mathrm{~mm}$. 
The stem was separated from the root and each tissue sample was stored in a $1.5 \mathrm{~mL}$ Eppendorf tube at $-80^{\circ} \mathrm{C}$.

Table 2. Soil physicochemical properties.

\begin{tabular}{cc}
\hline Parameter & Result \\
\hline Aluminum $(\mathrm{mg} / \mathrm{kg} \mathrm{wb})$ & 43,351 \\
Barium $(\mathrm{mg} / \mathrm{kg} \mathrm{wb})$ & 240 \\
Calcium $(\mathrm{mg} / \mathrm{kg} \mathrm{wb})$ & 7490 \\
Zinc $(\mathrm{mg} / \mathrm{kg} \mathrm{wb})$ & 61.5 \\
Iron $(\mathrm{mg} / \mathrm{kg} \mathrm{wb})$ & 19,573 \\
Magnesium $(\mathrm{mg} / \mathrm{kg} \mathrm{wb})$ & 1795 \\
Manganese $(\mathrm{mg} / \mathrm{kg} \mathrm{wb})$ & 778 \\
Potassium $(\mathrm{mg} / \mathrm{kg} \mathrm{wb})$ & 1457 \\
Sodium $(\mathrm{mg} / \mathrm{kg} \mathrm{wb})$ & 322 \\
pH $(\mathrm{mg} / \mathrm{kg} \mathrm{wb})$ & 6.07 \\
Electrical conductivity $(\mu \mathrm{S} / \mathrm{cm})$ & 4.3 \\
Field capacity $(\%)$ & 85 \\
Organic total carbon $(\mathrm{TOC})(\%)$ & 24.5 \\
Moisture content $(\%)$ & 63 \\
Particle size $(\mu \mathrm{m})$ & $150-300$ \\
Nitrogen $(\% \mathrm{db})$ & 0.054 \\
Bulk density $\left(\mathrm{g} / \mathrm{cm}^{3}\right)$ & 1.26 \\
\hline
\end{tabular}

\subsubsection{RNA Isolation}

Approximately $100 \mathrm{mg}$ of plant tissue (stem and root) were used. The samples were stored at $-80{ }^{\circ} \mathrm{C}$ in $1.5 \mathrm{~mL}$ Eppendorf tubes to avoid RNA degradation during the two days that the collection of all individuals lasted. For the extraction of RNA, an Agilent Plant RNA Isolation Mini Kit (Agilent Technologies, Santa Clara, CA, USA) was used, and the manufacturer's recommendations were followed.

The quantification of the RNA was performed utilizing a Nanodrop at a wavelength of $260 \mathrm{~nm}$. In the same way, the integrity of the extracted RNA was evaluated using a 1.5\% agarose electrophoresis. Subsequently, the isolated RNA was treated with DNase (Thermo Scientific, Waltham, MA, USA) leaving a final concentration of $20 \mathrm{ng} / \mu \mathrm{L}$ for all the tissues.

\subsubsection{Real-Time PCR}

The RT-qPCR was performed using the Brilliant III Ultra-Fast SYBR Green RT-qPCR Master Mix Kit (Agilent Technologies, Santa Clara, CA, USA). For each of the reactions, $2 \mu \mathrm{L}$ of RNA from each sample was used, according to the kit's requirements. Reactions were carried out in the Stratagene Mx3000p thermal cycler (Agilent Technologies, United States), using the temperature profile 1 cycle $50{ }^{\circ} \mathrm{C}$ for $10 \mathrm{~min}, 1 \mathrm{cycle} 95^{\circ} \mathrm{C}$ for $3 \mathrm{~min}, 40$ cycles $95{ }^{\circ} \mathrm{C}$ for $20 \mathrm{~s}$ and $60{ }^{\circ} \mathrm{C}$ or $62{ }^{\circ} \mathrm{C}$ for $20 \mathrm{~s}$. Finally, to verify the specificity of the amplification, a melting curve was performed at the end of each amplification. The temperature profile was $95^{\circ} \mathrm{C}$ for $1 \mathrm{~min}, 55^{\circ} \mathrm{C}$ for $30 \mathrm{~s}$, and $95^{\circ} \mathrm{C}$ for $30 \mathrm{~s}$; additionally, the amplicons were run in a $2 \%$ agarose electrophoresis. Quantification of the expression of the GST gene was performed using the delta $\mathrm{C}_{\mathrm{T}}$ (crossing threshold) method, using TBP-1 (which codes for TATA-box-binding protein) as a constitutive gene and a base of 1.8, assuming that the reaction did not have $100 \%$ efficiency. The primers used in the amplification process are shown in Table 3 . All RT-qPCR reactions were performed in duplicate, and if the obtained $\mathrm{C}_{\mathrm{T}}$ differed more than $5 \%$ this reaction was processed again.

\subsubsection{Plant Tissue Quantification}

At the end of the 30 days of growth, $0.5 \mathrm{~g}$ of soil, root, and stem of the plant were collected in each of the treatments, for a total of 18 samples that underwent acid digestion following the protocol established in the EPA-3051A, to quantify mercury concentration using ICP [45]. 
Table 3. Selected gene initiators used in qPCR reactions.

\begin{tabular}{ccccc}
\hline Name & Direction & Sequence & Size (pb) & $\begin{array}{c}\text { Temperature } \\
\text { Annealing }\left({ }^{\circ} \mathbf{C}\right)\end{array}$ \\
\hline \multirow{2}{*}{ GST } & $\left(5^{\prime}-3^{\prime}\right)$ & CTACAGAGCCACGCCGTCATCG & 193 & 62 \\
& $\left(3^{\prime}-5^{\prime}\right)$ & CAGCGTGGATCTGGGGTGCT & & 60 \\
\multirow{2}{*}{$T B P-1$} & $\left(5^{\prime}-3^{\prime}\right)$ & GCAGATATTCTTGATCCCGCTTT & 69 & 60 \\
\hline
\end{tabular}

\subsubsection{Analysis of Data}

For the data obtained from the stem and root measurements, the Shapiro-Wilk normality test was applied. From these data it has been found that the data did not present a normal distribution; comparisons of the lengths between treatments were made using the Kruskal-Wallis test. For both cases, a significance level of 0.05 was determined and both tests were carried out with the help of the software Minitab $2019^{\circledR}$.

\section{Results}

\subsection{Association Test}

After staining with $\mathrm{KOH}$ the selected roots of the mycorrhizal treatments, it could be shown that the association between L. perenne and mycorrhizal fungi occurred at all concentrations and with the first commercial (MICO1) preparation tested. The stained roots were observed under a light microscope and the images obtained are seen in Figure 1. For this study, the MICO1 mycorrhiza was chosen, presenting the only association in the roots of the plant and the least amount of inoculant.
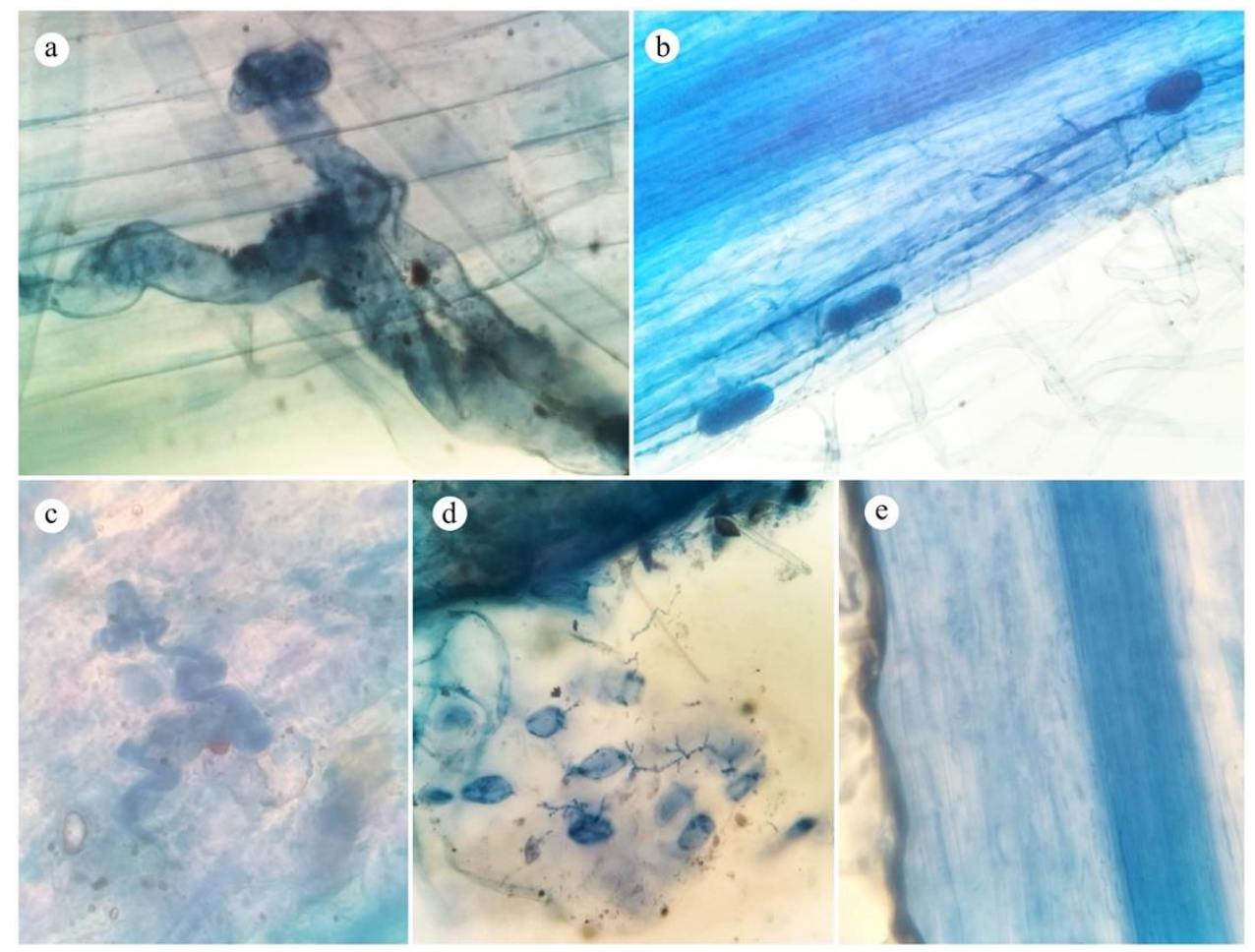

Figure 1. $\mathrm{KOH}$ staining results: (a) colonization hypha in the treatment of mercury with mycorrhizae $(100 \times)$; (b) vesicles in the control treatment with mycorrhizae $(40 \times)$; (c) colonization in the treatment of mercury with mycorrhizae $(100 \times)$; (d) vesicles in the treatment of mercury with mycorrhizas $(40 \times)$; (e) root without colonization of the control treatment. 


\subsection{Morphological Results}

Figure 2 shows the average lengths in centimeters of the different structures in each of the treatments evaluated. A multiple linear regression was performed in which the association and the metal or its absence were taken as factors $(n \approx 190)$. It has been found that none was statistically significant with a $p$-value greater than 0.05 for all the factors.

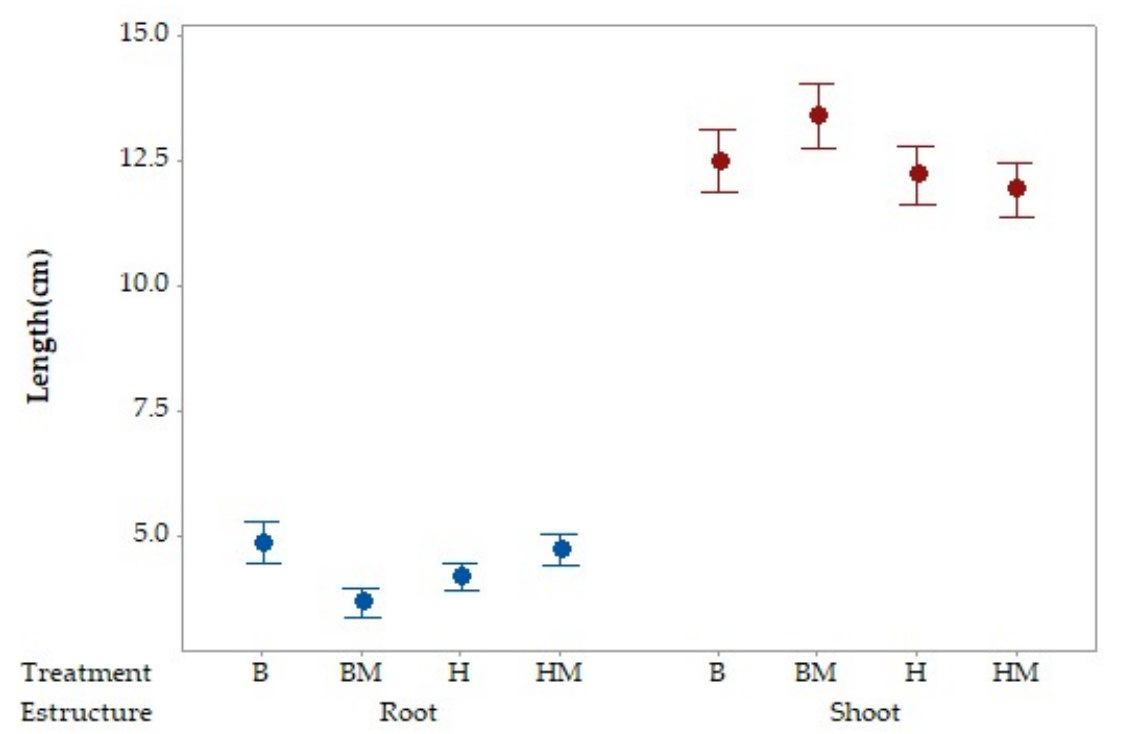

Figure 2. Interval plot of length $95 \% \mathrm{CI}$ of the mean (individual standard deviations are used to calculate the intervals).

Both the control (B) and the mercury treatment $(\mathrm{H})$ showed an average stem length that was similar, while in the case of the mercury-mycorrhizal (HM) treatments it was the one that showed an average-length minor stem. In the case of roots, the shortest length was observed in the control-mycorrhiza (BM), while in the other treatments the average length was very similar with a very small variation of millimeters between all.

Statistically it was obtained that the results were not significantly different; so, the length of the roots and stems of the different treatments were not different from those of the control (Figure 2).

\subsection{Heavy Metal Analysis}

Heavy metal tests were applied to the 18 samples collected after the phytoremediation process applied to mercury in soil by L. perenne. In Table 4, it is shown that when the plant was not in association with mycorrhiza, it was the stem structure that absorbed most contaminant, while when the plant was in symbiosis with the mycorrhiza, the root was the one that most absorbed the contaminant. However, the above behavior does not imply that the stem had higher growth; on the contrary, while the root was absorbing the pollutant, the growth of the stem was inhibited by almost $0.25 \mathrm{~cm}$ on average. While the root length in the two mycorrhiza treatments ( $\mathrm{H}$ and $\mathrm{HM}$ ) was similar, the absorption of the contaminant was higher in HM, which may be due to the fact that it was the mycorrhizae that were absorbing the metal. 
Table 4. Concentrations absorbed by mercury plant and soil structures.

\begin{tabular}{ccccc}
\hline Treatment & Matrix & Concentration Initial & Concentration Final & Units \\
\hline B & $\mathrm{S}$ & $<0.10$ & $<0.10$ & $\mathrm{mg} / \mathrm{kg}$ \\
$\mathrm{B}$ & $\mathrm{T}$ & & $<0.10$ & $\mathrm{mg} / \mathrm{kg}$ \\
$\mathrm{B}$ & $\mathrm{R}$ & $<0.10$ & $<0.10$ & $\mathrm{mg} / \mathrm{kg}$ \\
$\mathrm{BM}$ & $\mathrm{S}$ & & $<0.10$ & $\mathrm{mg} / \mathrm{kg}$ \\
$\mathrm{BM}$ & $\mathrm{T}$ & & $<0.10$ & $\mathrm{mg} / \mathrm{kg}$ \\
$\mathrm{BM}$ & $\mathrm{N}$ & & $<0.10$ & $\mathrm{mg} / \mathrm{kg}$ \\
$\mathrm{H}$ & $\mathrm{S}$ & & 0.29 & $\mathrm{mg} / \mathrm{kg}$ \\
$\mathrm{H}$ & $\mathrm{T}$ & 19 & 0.75 & $\mathrm{mg} / \mathrm{kg}$ \\
$\mathrm{H}$ & $\mathrm{N}$ & & 0.12 & $\mathrm{mg} / \mathrm{kg}$ \\
$\mathrm{HM}$ & $\mathrm{S}$ & & 0.41 & $\mathrm{mg} / \mathrm{kg}$ \\
$\mathrm{HM}$ & $\mathrm{T}$ & & 0.28 & $\mathrm{mg} / \mathrm{kg}$ \\
$\mathrm{HM}$ & $\mathrm{R}$ & & 0.49 & $\mathrm{mg} / \mathrm{kg}$ \\
\hline
\end{tabular}

Detection limits (DL) $0.10 \mathrm{mg} / \mathrm{kg}$. Acronyms: $\mathrm{S}=$ soil, $\mathrm{T}=$ stem, $\mathrm{R}=$ root.

As a result of the phytoremediation process carried out in soil contaminated with mercury, the following reduction in content was reached for each treatment: for $\mathrm{H}$, from 1.19 to $0.29 \mathrm{mg} / \mathrm{kg} \mathrm{dry}$ mass (75.6\%), and for HM, from 1.20 to $0.41 \mathrm{mg} / \mathrm{kg}$ dry mass $(65.8 \%)$. This was observed for 30 days of testing. The amount of mercury left in the soil without mycorrhiza $(\mathrm{H})$ was $0.18 \mathrm{mg}$, taking into account that the amount of mercury was $0.73 \mathrm{mg}$. Therefore, the mercury exported to the plant were $0.55 \mathrm{mg}$. For the treatment with mycorrhiza, the plant exported $0.48 \mathrm{mg}$ of mercury and $0.25 \mathrm{mg}$ remained in the soil.

\subsection{Molecular Analysis}

$\mathrm{C}_{\mathrm{T}}$ quantification for the GST gene was performed and compared with the $\mathrm{C}_{\mathrm{T}}$ of the selected constitutive gene. Samples were run in duplicate $(n=2)$. It was found, descriptively, that in the case of the control there was a decrease in the expression of the root when it presented an association with mycorrhiza; however, the expression levels were similar in the stem. On the other hand, in the case of mercury, increases were found in the levels of expression in both root and stem when there was the presence of an association with mycorrhiza. Figure 3 shows the level of expression for the different treatments.

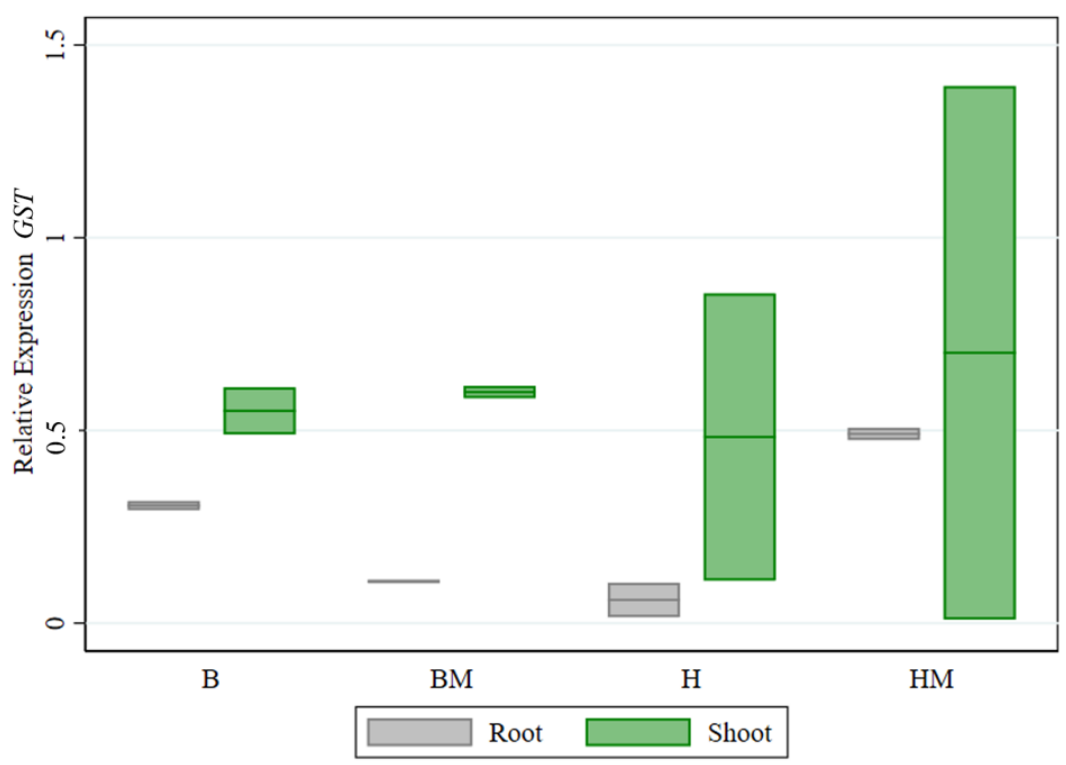

Figure 3. $C_{T}$ quantification for glutathione-S-transferase (GST) gene in comparison to $C_{T}$ of the selected constitutive gene $(n=2)$. 


\section{Discussion}

The association test was carried out to establish under which conditions mycorrhizal formed, and it was shown that this occurred both in the target and in the treatment with mercury. However, it could not be determined if the colonization rate was different between treatments since only two biological replicates were used; however, for future experiments the evaluation of the rate may be relevant for colonized roots in the presence and absence of heavy metals.

The establishment of micro-curls in the presence of heavy metals could occur since mycorrhizal fungi have various extracellular and intracellular defense mechanisms, such as the growth mechanism of vegetal tissue and biological nitrogen fixation mechanisms [20]. On the other hand, some authors argue that mycorrhizae possess antioxidant detoxification systems that aim to counteract the accumulation of reactive oxygen species (ROS) and mechanisms that focus on the repair of metal-damaged biomolecules [22,46,47]. According to the results of root growth and metal absorption, the comparison between plant-mycorrhizal symbiosis and plant alone can be explained taking into account that in arbuscular mycorrhizae, the mycelium extends from the roots of the plants through areas of depletion of poorly mobile nutrients, the most important being phosphorus [20]. Further, according to Smith and Read [16] the absorption surface area is considerably increased by the hypha network in the rhizosphere, acquiring nutrients and water more efficiently. Such behavior can be evidenced in the present work where even a higher absorption of metal in the root was observed when the plant was in symbiosis with mycorrhiza.

In the two treatments with and without mycorrhiza, a very similar longitudinal growth was observed, but in the absorption of the metal, it was observed that the highest percentage of absorption occurred in the treatment with mycorrhizae, and this behavior can be explained since the arbuscular mycorrhizae, with its extraradical mycelium that surrounds the roots of plants, not only extends the volume of the soil but also makes the absorption of nutritious minerals more efficient, also favoring the absorption of mercury [24,48-50]. This higher percentage of absorption in the root may be due to extracellular mechanisms, among which are chelation and binding to the cell wall, which focuses on the entry of metals. However, intracellular mechanisms, including non-protein thiol binding and transport to intracellular compartments, reduce the concentration of metals in the cytosol mechanisms [20]. According to the results shown in Table 4 and Figure 2, it can be suggested that the plant can absorb metals and also survive, developing properly and in a similar way to plants in soil without contamination.

A significant reduction of the contaminant in the soil with L. perenne was evidenced, in which a reduction was found for $\mathrm{H}$ of $75 \%$ and for $\mathrm{HM} 68 \%$, approximately. These results agree with those of other authors for both L. perenne and other species, which shows that $L$. perenne could be said to be a hyperaccumulating plant $[34,35,51]$.

There is evidence that arbuscular mycorrhizae play an important role in increasing the tolerance of some plants to toxic metal contamination by developing tolerance to fungal metals and binding of metals to polyphosphates within the fungal hyphae involved $[19,23,52]$. Preliminarily, it can be inferred that despite the bioaccumulative capacity of L. perenne, it is possible that part of the metals present in the soil as well as in the solution used for irrigation was captured by the different genus of fungi present in the mixture of mycorrhizae used.

Regarding the expression results of the GST gene, it was found that it was differentially regulated for $\mathrm{Hg}^{2+}$ when an association with mycorrhiza was present, which may be related to regulatory molecular activities to repair the damage, conferring tolerance to heavy metals. According to Shri et al. [53], heavy metal (oid) exposure to plants increases GSH content, which has been correlated with the feedback induction and increased expression of genes encoding members of GST and glutathione peroxidases (GPX) gene families under as stress. Collectively, the combined positive regulation of the gene and the association with mycorrhizae may contribute to a superior ability to adapt to $\mathrm{Hg}^{2+}$ in L. perenne [25], which can be observed morphologically in the elongation of early structures (Table 2). This behavior could take place by cause of the glutathione-S-transferase (GST) gene found in 
plants in the cytosol, being homo or heterodimeric enzymes that exist as multiple isoenzymes with species-specific activity for a wide spectrum of electrophilic compounds. These enzymes can also catalyze the conjugation between various xenobiotic compounds with electrophilic centers, such as those produced by $\mathrm{Hg}^{2+}$ metal ions, and the nucleophile glutathione (GSH), thus marking the xenobiotic for vacuolar sequestration $[54,55]$. The resulting GSHu conjugates are generally less toxic and more soluble in water than the original xenobiotics $[56,57]$.

According to the results, it can be inferred that mercury was detoxified by the conjugation of glutathione catalyzed by GST. Consequently, in this study, it can be seen that the activity of the GST protein was blocked, which could have led to an accumulation of unconjugated electrophiles in the cell, or in this case, as expressed by other authors, they can find cytosolic enzymes which could be causing the conversion to toxic metabolites $[28,31,58]$. In the same way, treatment with mycorrhiza could help the proper development of the plant because a large fraction of the metal is accumulated in the roots and mycelia of arbuscular mycorrhizae, so the elimination of conjugates from the cytoplasm and its compartmentalization and immobilization in the cell is critical for effective detoxification.

In the phytoremediation process, toxic substances present in the soil can be retained or metabolized by the plant. In the case of L. perenne, if it is exposed to heavy metals, these can accumulate within the root or aerial structures such as leaves or stems [26]. There are plant species that are capable of volatilizing metals such as $\mathrm{Se}, \mathrm{Hg}$, and As that have accumulated in the aerial tissues [27]. However, there is not enough information to confirm that this is the case with L. perenne; although according to the metal balance test performed it can be stated that in the 30 days of treatment the metal was not volatilized by the plant.

From the treatment of contaminated soil without mycorrhizae, the greatest accumulation occurred in the stem; the concentration of the metal was greater than the concentration present in the soil. In the case of mycorrhizal treatments, a different trend was seen, since the greatest accumulation was seen in the root. The fact that mercury concentrations were higher inside the plant and the root than in the soil indicates that a process of phytoremediation took place. It is necessary to continue evaluating the plant-mycorrhizal symbiosis to determine how much the mycorrhiza helps the development of the plant and the absorption of a greater amount of metal, or whether this symbiosis is not necessary, because it was not evaluated whether the colonization rate was lower in these treatments concerning the treatment of control with mycorrhizae. However, it can be seen from the results that the symbiosis does affect the way the plant assimilates the contaminant.

\section{Conclusions}

Taking all the results into account, it can be concluded that L. perenne may be a good alternative to remove mercury from the soil. From the morphological results it can be concluded that the symbiosis of L. perenne and arbuscular mycorrhizal fungi reduces root development and stimulates stem growth, although other species and families of arbuscular mycorrhizal fungi could be evaluated to determine if they are better than those evaluated in this study, such as Rhizoglomus intraradices, Glomus macrocarpum, and the Basidiomycetes family. At the molecular level, it was observed that for the GST gene, there was a differential response for mycorrhizal treatments, which is important because this gene encodes proteins that help eliminate toxins in the plant. However, in the case of $\mathrm{Hg}^{2+}$, it is possible that an accumulation of glutathione could have occurred in the cells without the possibility of expulsion and consequently it could also have resulted in a toxic effect. It is necessary then, to continue studying L. perenne as a mercury phytoremediator plant, including or considering more genes that can determine how the plant's structures can be affected by the remediation of metals such as mercury. Likewise, we should evaluate other enzymes such as CAT, pAPX, Hsp70, Hsp90, and GPX. Errors in the mercury mass balance may be due to sampling and equipment accuracy that may have caused an error of approximately $1.17 \%$. 
Author Contributions: Conceptualization, J.F.S. and C.M.-R.; methodology, J.F.S., C.M.-R., M.d.P.D.; software, Y.C. and A.M.L.; validation, J.F.S., C.M.-R. and M.d.P.D.; formal analysis, J.F.S.; investigation, A.M.L., Y.C., C.M.-R., M.d.P.D. and J.F.S.; resources, J.F.S. and M.d.P.D.; data curation, A.M.L. and Y.C.; writing-original draft preparation, J.F.S., Y.C., A.M.L. and C.M.-R.; writing-review and editing, C.M.-R., J.F.S. and M.d.P.D.; visualization, C.M.-R., J.F.S. and M.d.P.D.; supervision, J.F.S., C.M.-R. and M.d.P.D.; project administration, J.F.S.; funding acquisition, J.F.S. All authors have read and agreed to the published version of the manuscript.

Funding: This research received no external funding.

Acknowledgments: This work was carried out with financial support from the Department of Civil and Environmental Engineering at Universidad de los Andes. This publication was partially made possible by the call for proposals CI-0120: "Publish your new knowledge or expose your new creations" from the Office Vice President for Research and Creation at Universidad de los Andes.

Conflicts of Interest: The authors declare no conflicts of interest.

\section{References}

1. Slemr, F.; Brunke, E.-G.; Ebinghaus, R.; Temme, C.; Munthe, J.; Wängberg, I.; Schroeder, W.; Steffen, A.; Berg, T. Worldwide trend of atmospheric mercury since 1977. Geophys. Res. Lett. 2003, 30. [CrossRef]

2. Biester, H.; Bindler, R.; Martinez-Cortizas, A.; Engstrom, D.R. Modeling the Past Atmospheric Deposition of Mercury Using Natural Archives. Environ. Sci. Technol. 2007, 41, 4851-4860. [CrossRef] [PubMed]

3. Martínez-Cortizas, A.; Pontevedra-Pombal, X.; García-Rodeja, E.; Nóvoa-Muñoz, J.C.; Shotyk, W. Mercury in a Spanish Peat Bog: Archive of Climate Change and Atmospheric Metal Deposition. Science 1999, 284, 939-942. [CrossRef] [PubMed]

4. Skyllberg, U. Chapter 13-Mercury Biogeochemistry in Soils and Sediments. In Developments in Soil Science; Singh, B., Gräfe, M., Eds.; Synchrotron-Based Techniques in Soils and Sediments; Elsevier: Burlington, VT, USA, 2010; Volume 34, pp. 379-410.

5. Håkanson, L. A simple model to predict the duration of the mercury problem in Sweden. Ecol. Model. 1996, 93, 251-262. [CrossRef]

6. Hylander, L.D.; Meili, M. The Rise and Fall of Mercury: Converting a Resource to Refuse after 500 Years of Mining and Pollution. Crit. Rev. Environ. Sci. Technol. 2005, 35, 1-36. [CrossRef]

7. Glick, B.R. Using soil bacteria to facilitate phytoremediation. Biotechnol. Adv. 2010, 28, 367-374. [CrossRef]

8. Gupta, P.; Rani, R.; Usmani, Z.; Chandra, A.; Kumar, V. Chapter 5-The Role of Plant-Associated Bacteria in Phytoremediation of Trace Metals in Contaminated Soils. In New and Future Developments in Microbial Biotechnology and Bioengineering; Singh, J.S., Singh, D.P., Eds.; Elsevier: Burlington, VT, USA, 2019; pp. 69-76, ISBN 978-0-444-64191-5.

9. Girma, G. Microbial Bioremediation of some Heavy Metals in Soils: An updated review. J. Resour. Dev. Manag. 2015, 10, 62-73. [CrossRef]

10. Boudh, S.; Tiwari, S.; Singh, J.S. Microbial-Mediated Lindane Bioremediation. In Agro-Environmental Sustainability: Volume 2: Managing Environmental Pollution; Singh, J.S., Seneviratne, G., Eds.; Springer International Publishing: Cham, Switzerland, 2017; pp. 213-233, ISBN 978-3-319-49727-3.

11. Vargas Aguirre, C.F.; Rivera Páez, F.A.; Escobar Vargas, S. Effect of arbuscular mycorrhizae and mercury on Lactuca sativa (Asteraceae) seedling morpho-Histology. Environ. Exp. Bot. 2018, 156, 197-202. [CrossRef]

12. Begon, M.; Harper, J.L.; Townsend, C.R. Ecology. Individuals, Populations and Communities; Blackwell Scientific Publications: Oxford, UK, 1986; ISBN 0-632-01337-0.

13. Schulz, S.; Brankatschk, R.; Dümig, A.; Kögel-Knabner, I.; Schloter, M.; Zeyer, J. The role of microorganisms at different stages of ecosystem development for soil formation. Biogeosciences 2013, 10, 3983-3996. [CrossRef]

14. Nicolson, T.H. Vesicular arbuscular mycorrhiza a universal plant symbiosis. Sci. Prog. 1967, 55, 561-581.

15. Marks, G.C.; Kozlowski, T.T. Ectomycorrhizae, Their Ecology and Physiology; Academic Press: New York, NY, USA, 1973; ISBN 0-12-472850-2.

16. Smith, S.; Read, D. Mycorrhizal Symbiosis, 3rd ed.; Academic Press: London, UK, 2008; ISBN 978-0-08-055934-6.

17. Luginbuehl, L.H.; Menard, G.N.; Kurup, S.; Erp, H.V.; Radhakrishnan, G.V.; Breakspear, A.; Oldroyd, G.E.D.; Eastmond, P.J. Fatty acids in arbuscular mycorrhizal fungi are synthesized by the host plant. Science 2017, 356, 1175-1178. [CrossRef] [PubMed]

18. Gianiazzi, S.; Schüepp, H. (Eds.) Impact of Arbuscular Mycorrhizas on Sustainable Agriculture and Natural Ecosystems; Advances in Life Sciences; Birkhäuser Basel: Basel, Switzerland, 1994; ISBN 978-3-0348-9654-2. 
19. Leung, H.-M.; Wang, Z.-W.; Ye, Z.-H.; Yung, K.-L.; Peng, X.-L.; Cheung, K.-C. Interactions between Arbuscular Mycorrhizae and Plants in Phytoremediation of Metal-Contaminated Soils: A Review. Pedosphere 2013, 23, 549-563. [CrossRef]

20. Coninx, L.; Martinova, V.; Rineau, F. Chapter Four-Mycorrhiza-Assisted Phytoremediation. In Advances in Botanical Research; Cuypers, A., Vangronsveld, J., Eds.; Phytoremediation; Academic Press: London, UK, 2017; Volume 83, pp. 127-188.

21. Sylvia, D.M.; Fuhrmann, J.J.; Hartel, P.G.; Zuberer, D.A. Principles and Applications of Soil Microbiology, 2nd ed.; Prentice Hall: Upper Saddle River, NJ, USA, 2004; ISBN 978-0-13-094117-6.

22. Cabral, L.; Soares, C.R.F.S.; Giachini, A.J.; Siqueira, J.O. Arbuscular mycorrhizal fungi in phytoremediation of contaminated areas by trace elements: Mechanisms and major benefits of their applications. World J. Microbiol. Biotechnol. 2015, 31, 1655-1664. [CrossRef] [PubMed]

23. Barea, J.-M.; Pozo, M.J.; Azcón, R.; Azcón-Aguilar, C. Microbial co-operation in the rhizosphere. J. Exp. Bot. 2005, 56, 1761-1778. [CrossRef]

24. Gosling, P.; Hodge, A.; Goodlass, G.; Bending, G.D. Arbuscular mycorrhizal fungi and organic farming. Agric. Ecosyst. Environ. 2006, 113, 17-35. [CrossRef]

25. $\mathrm{Li}, \mathrm{H} . ; \mathrm{Hu}, \mathrm{T} . ; \mathrm{Fu}$, J. Identification of genes associated with adaptation to $\mathrm{NaCl}$ toxicity in perennial ryegrass (Lolium perenne L.). Ecotoxicol. Environ. Saf. 2012, 79, 153-162. [CrossRef]

26. Hasegawa, P.M.; Bressan, R.A.; Zhu, J.-K.; Bohnert, H.J. Plant Cellular and Molecular Responses to High Salinity. Annu. Rev. Plant Physiol. Plant Mol. Biol. 2000, 51, 463-499. [CrossRef]

27. Cummins, I.; Dixon, D.P.; Freitag-Pohl, S.; Skipsey, M.; Edwards, R. Multiple roles for plant glutathione transferases in xenobiotic detoxification. Drug Metab. Rev. 2011, 43, 266-280. [CrossRef]

28. Kumar, S.; Trivedi, P.K. Glutathione S-Transferases: Role in Combating Abiotic Stresses Including Arsenic Detoxification in Plants. Front. Plant Sci. 2018, 9. [CrossRef]

29. Frova, C. Glutathione transferases in the genomics era: New insights and perspectives. Biomol. Eng. 2006, 23, 149-169. [CrossRef]

30. Gutiérrez Ginés, M.J.; Hernández, A.J.; Pastor Piñeiro, J. Estudio del comportamiento de Lolium perenne L. en suelos del Centro de España contaminados por metales pesados. In Control de la Degradación y uso Sostenible del Suelo; Universidad de Valencia: Valencia, Spain, 2011; ISBN 978-84-615-1679-7.

31. Coleman, J.; Blake-Kalff, M.; Davies, E. Detoxification of xenobiotics by plants: Chemical modification and vacuolar compartmentation. Trends Plant Sci. 1997, 2, 144-151. [CrossRef]

32. Kubik, C.; Sawkins, M.; Meyer, W.A.; Gaut, B.S. Genetic Diversity in Seven Perennial Ryegrass (Lolium perenne L.) Cultivars Based on SSR Markers. Crop Sci. 2001, 41, 1565-1572. [CrossRef]

33. Xing, Y.; Frei, U.; Schejbel, B.; Asp, T.; Lübberstedt, T. Nucleotide diversity and linkage disequilibrium in 11 expressed resistance candidate genes in Lolium perenne. BMC Plant Biol. 2007, 7, 43. [CrossRef] [PubMed]

34. Al-Attar, A.F.; Nickless, G. Response surface methodology for an investigation of the influence of selenium, cadmium and mercury on the growth of Lolium perenne seedings. Chemosphere 1988, 17, 1851-1861. [CrossRef]

35. Wong, M.H.; Bradshaw, A.D. A Comparison of the Toxicity of Heavy Metals, Using Root Elongation of Rye Grass, Lolium perenne. New Phytol. 1982, 91, 255-261. [CrossRef]

36. Reis, A.T.; Rodrigues, S.M.; Araújo, C.; Coelho, J.P.; Pereira, E.; Duarte, A.C. Mercury contamination in the vicinity of a chlor-alkali plant and potential risks to local population. Sci. Total Environ. 2009, 407, 2689-2700. [CrossRef]

37. Jensen, L.B.; Muylle, H.; Arens, P.; Andersen, C.H.; Holm, P.B.; Ghesquiere, M.; Julier, B.; Lübberstedt, T.; Nielsen, K.K.; Riek, J.D.; et al. Development and mapping of a public reference set of SSR markers in Lolium perenne L. Mol. Ecol. Notes 2005, 5, 951-957. [CrossRef]

38. King, J.; Thorogood, D.; Edwards, K.J.; Armstead, I.P.; Roberts, L.; Skøt, K.; Hanley, Z.; King, I.P. Development of a Genomic Microsatellite Library in Perennial Ryegrass (Lolium perenne) and its Use in Trait Mapping. Ann. Bot. 2008, 101, 845-853. [CrossRef]

39. Jia, H.; Hou, D.; O'Connor, D.; Pan, S.; Zhu, J.; Bolan, N.S.; Mulder, J. Exogenous phosphorus treatment facilitates chelation-mediated cadmium detoxification in perennial ryegrass (Lolium perenne L.). J. Hazard. Mater. 2020, 389, 121849. [CrossRef] 
40. Ju, X.H.; Tang, S.; Jia, Y.; Guo, J.; Ding, Y.; Song, Z.; Zhao, Y. Determination and characterization of cysteine, glutathione and phytochelatins (PC2-6) in Lolium perenne L. exposed to Cd stress under ambient and elevated carbon dioxide using HPLC with fluorescence detection. J. Chromatogr. B 2011, 879, 1717-1724. [CrossRef] [PubMed]

41. Hu, Y.; Habibul, N.; Hu, Y.-Y.; Meng, F.-L.; Zhang, X.; Sheng, G.-P. Mixture toxicity and uptake of 1-butyl-3-methylimidazolium bromide and cadmium co-contaminants in water by perennial ryegrass (Lolium perenne L.). J. Hazard. Mater. 2020, 386, 121972. [CrossRef] [PubMed]

42. Cepero de García, M.C.; Restrepo, S.; Franco-Molano, A.E.; Cárdenas, M.; Vargas, N.V. Biología de Hongos, 1st ed.; Universidad de los Andes: Bogotá, Colombia, 2012; ISBN 978-958-695-701-4.

43. Haidouti, C. Inactivation of mercury in contaminated soils using natural zeolites. Sci. Total Environ. 1997, 208, 105-109. [CrossRef]

44. Pitombeira de Figueirêdo, L.; Daam, M.A.; Mainardi, G.; Mariën, J.; Espíndola, E.L.G.; van Gestel, C.A.M.; Roelofs, D. The use of gene expression to unravel the single and mixture toxicity of abamectin and difenoconazole on survival and reproduction of the springtail Folsomia candida. Environ. Pollut. 2019, 244, 342-350. [CrossRef] [PubMed]

45. United States Environmental Protection Agency. EPA Method 3051A: Microwave Assisted Acid Digestion of Sediments, Sludges, and Oils. Available online: https://www.epa.gov/esam/us-epa-method-3051amicrowave-assisted-acid-digestion-sediments-sludges-and-oils (accessed on 24 March 2020).

46. Bellion, M.; Courbot, M.; Jacob, C.; Blaudez, D.; Chalot, M. Extracellular and cellular mechanisms sustaining metal tolerance in ectomycorrhizal fungi. FEMS Microbiol. Lett. 2006, 254, 173-181. [CrossRef] [PubMed]

47. Daghino, S.; Martino, E.; Perotto, S. Model systems to unravel the molecular mechanisms of heavy metal tolerance in the ericoid mycorrhizal symbiosis. Mycorrhiza 2016, 26, 263-274. [CrossRef] [PubMed]

48. Tarraf, W.; Ruta, C.; Tagarelli, A.; De Cillis, F.; De Mastro, G. Influence of arbuscular mycorrhizae on plant growth, essential oil production and phosphorus uptake of Salvia officinalis L. Ind. Crops Prod. 2017, 102, 144-153. [CrossRef]

49. Azcón, R.; Ambrosano, E.; Charest, C. Nutrient acquisition in mycorrhizal lettuce plants under different phosphorus and nitrogen concentration. Plant Sci. 2003, 165, 1137-1145. [CrossRef]

50. Schnepf, A.; Jones, D.; Roose, T. Modelling Nutrient Uptake by Individual Hyphae of Arbuscular Mycorrhizal Fungi: Temporal and Spatial Scales for an Experimental Design. Bull. Math. Biol. 2011, 73, 2175-2200. [CrossRef]

51. Steliga, T.; Kluk, D. Application of Festuca arundinacea in phytoremediation of soils contaminated with $\mathrm{Pb}$, $\mathrm{Ni}, \mathrm{Cd}$ and petroleum hydrocarbons. Ecotoxicol. Environ. Saf. 2020, 194, 110409. [CrossRef]

52. Morgan, J.A.W.; Bending, G.D.; White, P.J. Biological costs and benefits to plant-microbe interactions in the rhizosphere. J. Exp. Bot. 2005, 56, 1729-1739. [CrossRef]

53. Shri, M.; Kumar, S.; Chakrabarty, D.; Trivedi, P.K.; Mallick, S.; Misra, P.; Shukla, D.; Mishra, S.; Srivastava, S.; Tripathi, R.D.; et al. Effect of arsenic on growth, oxidative stress, and antioxidant system in rice seedlings. Ecotoxicol. Environ. Saf. 2009, 72, 1102-1110. [CrossRef] [PubMed]

54. Martinoia, E.; Grill, E.; Tommasini, R.; Kreuz, K.; Amrhein, N. ATP-dependent glutathione S -conjugate "export" pump in the vacuolar membrane of plants. Nature 1993, 364, 247-249. [CrossRef]

55. Xi, Y.; Jiao, W.; Cao, J.; Jiang, W. Effects of chlorogenic acid on capacity of free radicals scavenging and proteomic changes in postharvest fruit of nectarine. PLoS ONE 2017, 12, e0182494. [CrossRef] [PubMed]

56. Brown, H.M.; Neighbors, S.M. Soybean metabolism of chlorimuron ethyl: Physiological basis for soybean selectivity. Pestic. Biochem. Physiol. 1987, 29, 112-120. [CrossRef]

57. Dixon, D.P.; Davis, B.G.; Edwards, R. Functional Divergence in the Glutathione Transferase Superfamily in Plants identification of two classes with putative functions in redox homeostasis in arabidopsis thaliana. J. Biol. Chem. 2002, 277, 30859-30869. [CrossRef]

58. Gullner, G.; Uotila, M.; Kömives, T. Responses of Glutathione and Glutathione S-Transferase to Cadmium and Mercury Exposure in Pedunculate Oak (Quercus robur) Leaf Discs. Bot. Acta 1998, 111, 62-65. [CrossRef]

(C) 2020 by the authors. Licensee MDPI, Basel, Switzerland. This article is an open access article distributed under the terms and conditions of the Creative Commons Attribution (CC BY) license (http://creativecommons.org/licenses/by/4.0/). 